do semblante ela é uma bússola imprescindível para a condução do tratamento e o final da análise. Aqui a orientação de Miller ${ }^{4}$ é novamente eixo. Em A experiência do real, ele parte do caráter, afirmando o sinthoma como misto de sintoma e caráter. Para a autora, este caminho não toma o caráter como substituto da fantasia, mas contorna o problema relativo à sexuação feminina, pois do lado feminino não pode haver fantasia. No entanto, pode haver caráter. Com Freud e Lacan ela situa, de um lado, a sexuação masculina enquanto atravessada pelo "ao menos um" da castração e pelo imperativo de renúncia e, de outro, a feminina, marcada por uma reivindicação: ser tratada como exceção em função da suposição comum às mulheres de terem sofrido uma lesão a mais em relação ao resto da humanidade. "O modo de representação do feminino passa pela lesão, pelo buraco" (p.118).

A recuperação do conceito de caráter organiza o campo da sexualidade feminina diante da impossibilidade de situar a fantasia do lado feminino na partilha sexual. Sem isso, correríamos o risco de tomar a devastação feminina como intratável, inefável, impossível ou indizível, vias que certamente levariam o analista a "um gozo teórico com o nada", ou seja, com a fal ta de conceito (p.119-120). Ora, o gozo com a falta não se configura como caminho que permita distinguir 0 desejo inconsciente e o desejo do analista. Ao não escolher esta via, Tania Coelho dos Santos dá testemunho de que a formação do analista é árdua, mas não é aí onde, verdadeiramente, se situa 0 impossível da tarefa de analisar ao qual Freud se referiu.

4 MILLER, J.A. (1998-99/2003) La experiencia de lo real en la cura psicoanalítica. Buenos Aires: Paidós.
Recebida em 23/ 8/ 2006.

Rosa Guedes Lopes

rosa.guedes.lopes@globo.com

\section{RESISTIR É PRECISO}

\section{Arquivos do mal-estar e da}

resistência. Joel Birman. Rio de

Janeiro: Civilização Brasileira, 2006, $418 p$.

Regina Herzog

Psicanalista; professora adjunta do Programa de Pós-graduação em Teoria Psicanalítica, UFRJ.

0 mal-estar na atualidade e a resistência compõem um campo que, há um bom tempo, já vem sendo freqüentado por Joel Birman. 0 interesse maior, neste campo, se refere à condição humana e se faz na interface com vários saberes sem que se perca, em momento algum, a referência ao lugar que este autor ocupa em nosso meio. Seu campo de pesquisa é o campo psicanalítico e sua preocupação é com o sofrimento psíquico que acomete os indivíduos.

É nesta perspectiva que Birman nos presenteia com sua mais nova produção. Arquivos do mal-estar e da resistência dispensa apresentação. Trata-se de um conjunto de textos, alguns extraídos de conferências, outros de suas aulas. A novidade fica por conta do modo como os diversos temas abordados foram dispostos. Dividido em três partes - Da servidão à fraternidade, Poder e subjetivação e Desejo de resistência - cada bloco se articula com os demais, constituindo uma trama que deixa à mostra o modo de pensar do autor.

Começando com a questão 'da servidão à fraternidade', Birman nos convida 
a enfrentar a expressão "servidão voluntária", nos introduzindo "nos pressupostos éticos da condição humana". Sua ousadia, neste artigo, foi de mostrar os impasses éticos, preconizados por La Boétie, séculos atrás, que dizem respeito ao próprio campo da psicanálise.

Nesta direção, o autor dá continuidade à discussão, abordando a questão da psicanálise e a crítica da modernidade, visando indicar que "o compromisso ético e político com o modernismo" que caracteriza a psicanálise é o grande desafio com que nos deparamos hoje, neste "tempo de trevas da pós-modernidade". Na medida que sua investigação se insere nas questões atuais e, ainda, por nunca ter se afastado de seu compromisso com nossa realidade, Birman é levado a falar, no terceiro artigo deste bloco, no malestar presente hoje no Brasil, apontando os efeitos produzidos no "território da vergonha" tanto no registro coletivo quanto no individual.

Cada artigo se constitui como um desafio; a discussão envereda para a idéia de barbárie, como o que funda a civilização. 0 autor, neste texto, nos presenteia com uma leitura trágica sobre a modernidade, aproximando-a do modo como a psicanálise pensa esta questão.

Nos dois últimos artigos da primeira parte, o tema escolhido é o da fraternidade no pensamento freudiano; e para abordá-lo, Birman se serve de três filmes da atualidade, o que confere a esta discussão um colorido ímpar. Seu objetivo é mostrar que "o que deve catalisar hoje as novas formas de laços fraternos é a feminilidade como modalidade de construção do sujeito..." (p.138) As considerações acerca desta figura ganham profundidade no segundo trabalho, em que 0 autor discute os destinos e impasses da figura do pai na atualidade.
$\mathrm{Na}$ segunda parte, os artigos estão centrados nas questões do poder e da subjetivação. 0 fio condutor, aí, diz respeito às transformações que vêm tendo lugar nos dias atuais, tanto no âmbito social quanto individual. Neste conjunto de artigos, a maioria sendo conferências proferidas aqui e no exterior, Birman faz uma análise minuciosa, do ponto de vista ético, das problemáticas que envolvem as novas formas de subjetivação, salientando como o "mal-estar se evidencia agora nos registros do corpo, da ação e do sentimento" (p.174). Cada figura trabal hada - o vazio, a compulsão, o tempo que explode - ganham relevo e se prestam a denunciar como "ficamos amesquinhados como sujeitos" e "incapazes de criar mediações no mundo" (p.193).

Para este autor, cada tema funciona como uma provocação. Em "Reviravoltas na soberania", trata da questão do poder, mas sem deixar de lado o campo da psicanálise, visto considerar, mui apropriadamente, que as novas formas de subjetivação são, em última instância, um efeito eloqüente da "construção dos diversos espaços de poder" (p.202). É interessante acompanhar sua argumentação, quando retoma as figuras do artigo anterior para abrir uma outra via de interpretação.

A proposta de uma genealogia do assédio dá continuidade ao objetivo que, em última instância, perpassa todo o livro, qual seja: mostrar como, na atualidade, determinadas figuras ganham relevo e muitas vezes não são devidamente interpretadas. Daí a necessidade, para Birman, de delinear os solos social e histórico nos quais germinam tais figuras. Sem dúvida, este modo de abordar os problemas confere um outro valor aos temas estudados. Isto se confirma quando ele volta sua atenção para uma outra noção, a biopolítica. A discussão, neste artigo, 
mostra quando e como a biopolítica entra em cena na história do Ocidente, chegando, nos dias de hoje, a assumir outras direções, realizando-se no campo da sexualidade para buscar entender o modo como vão se constituir as novas filiações e as novas genealogias.

Certamente, não poderia faltar, neste conjunto, uma discussão sobre a criminalidade. 0 texto é denso e denuncia de forma clara o modo como o controle é exercido; mas convida, também, a resistir, através da afirmação de que podemos pensar tanto a loucura quanto o mal-estar "como fonte de obra".

0 último artigo volta a trabalhar os impasses da psicanálise na atualidade, e nele se propõe "empreender uma leitura crítica sobre o que está em pauta na construção do discurso psicanalítico" (p.299).

Finalizando a obra, a terceira parte congrega quatro artigos em torno do desejo de resistência, cuja característica maior diz respeito a uma aposta: a de que resistir é preciso. Iniciando por uma genealogia da resistência, Birman aborda, em seqüência, a questão da transgressão, salientando como "a experiência psicanalítica, ao reconhecer e dar acolhimento ao pólo transgressivo do psiquismo, é um percurso que implica a presença da vida nua na subjetividade" (p.368).

Os dois últimos textos abordam um assunto polêmico: a questão judaica - a constituição do Estado palestino, o Estado de Israel, a judeidade de Freud. Neles, o desejo de resistência está mais forte ainda.

Recebida em 27/ 9/ 2006.

Regina H erzog

rherzog@globo.com 